\title{
Of Raids and Returns: Sex work movement, police oppression, and the politics of the ordinary in Sonagachi, India
}

\author{
Simanti Dasgupta
}

\begin{abstract}
Drawing on ethnographic work with Durbar Mahila Samanwaya Committee (DMSC), a grassroots sex worker organisation in Sonagachi, the iconic redlight district in Kolkata, India, this paper explores the politics of the detritus generated by raids as a form of state violence. While the current literature mainly focuses on its institutional ramifications, this article explores the significance of the raid in its immediate relation to the brothel as a home and a space to collectivise for labour rights. Drawing on atyachar (oppression), the Bengali word sex workers use to depict the violence of raids, I argue that they experience the raid not as a spectacle, but as an ordinary form of violence in contrast to their extraordinary experience of return to rebuild their lives. Return signals both a reclamation of the detritus as well as subversion of the state's attempt to undermine DMSC's labour movement.
\end{abstract}

Keywords: sex work, law, labour, raids, police violence, India

Suggested citation: S Dasgupta, 'Of Raids and Returns: Sex work movement, police oppression, and the politics of the ordinary in Sonagachi, India', AntiTrafficking Review, issue 12, 2019, pp. 127-139, www.antitraffickingreview.org

That morning, the phone rang earlier than usual. It was around 6:30, and I was barely waking up from the fatigue of witnessing a police raid that occurred the previous evening in Sonagachi, the iconic red-light district in Kolkata that is my current fieldwork site. I answered the phone and recognised Nita-di's voice on the other end. I was glad to hear from her as she was one of the women in that brothel who managed to escape. We had been out of touch overnight, and I had hoped that she was safe. 'How are you and where are you?', I immediately wanted to know. 'I am ok, don't worry', she said, 'I was able to escape since I saw the police vans turn the corner of our street from my window. It was quick, but I managed.' 'But where are you now?', I asked her. She evaded the question and requested I meet her that afternoon at a tea stall,

This is an open-access article distributed under the terms of the Creative Commons Attribution License (CC-BY). Under the CC-BY license, the public is free to share, adapt, and make commercial use of the work. Users must always give proper attribution to the authors and the Anti-Trafficking Review. 
saying, 'I have something that I need you to do for me. If you can, deliver the gift I have for my granddaughter.' For the past few days, Nita-di had been talking about her granddaughter's birthday and how she had been saving up money to buy her a present, 'a tiny pair of gold earrings', she had told me. Her daughter, who I eventually learnt was (unofficially) adopted, had moved out of Sonagachi mainly to distance herself from the stigma of prostitution that her mother carried. Nita-di's relationship with her adoptive daughter had been estranged for years, but she still yearned for connection with her and was trying hard to cling to the grandchild.

We met at the designated footpath tea stall that afternoon. Nita-di looked fatigued and restless. As we sat down on the rickety wooden bench, she asked me how I was doing. Though this was not my first time witnessing a police raid, I was truly shaken at the spectacle of the violence and was still wrestling with its remarkable brutality. She put her hand assuringly on mine and said, 'It makes sense that you are shaken; you are not used to such things, but, as you know, the raids are only one of the many things we endure in Sonagachi', raising her index finger for emphasis. 'We withstand so much every day that often I do not even know what will happen tomorrow, where I will be, where I will sleep. I thought the raids went down after we formed DMSC but (it) seems like the police oppression is on the rise again.' Before leaving, I asked when I would see her again. She responded, 'When it gets quieter, I will return to my ghar (home).' That evening I took the gift to Nita-di's daughter's house, but she refused to accept it. I called Nita-di with the update. She only said, 'When I return, I will try again'.

In this article, I draw on my ethnographic research with Durbar Mahila Samanwaya Committee (DMSC), a grassroots sex worker organisation in Sonagachi established in 1995 at the peak of the HIV/AIDS epidemic. Since 2010, my research has involved sites such as DMSC offices and clinics, brothels, police stations, state offices, and local hospitals. Here, I specifically concentrate on a raid that occurred in June 2014 at NandaRanir Bari, as a paradigmatic example. All the names used here (except Purnima-di's ${ }^{1}$ ) are pseudonyms, and I have scrambled the biographies of sex workers to protect their anonymity. The first section, titled 'What is a Raid?', emphasises the disjuncture between the raid as an institutional surveillance device and the sex workers' lived experience of it. Next, 'The Human Trace' presents the unfolding of the raid one afternoon followed by my visit to NandaRanir Bari the next day where I describe the trail of destruction-broken locks, strewn clothes - and recount the lives of the women summoned by the detritus. To draw out the implication the raid has for the sex workers who have been apprehended as

1 Purnima-di, a veteran and retired sex worker, was my primary informant in the field. She was keen that I use her real name so that 'the work that I have done lives on'. 
presumed minors, I present an exchange with officials at the Child Welfare Committee, and how the state uses the anti-trafficking narrative and the protection of children to disregard the labour movement in Sonagachi. The following section, 'Broken Pieces', focuses on Nita-di's return to NandaRanir Bari, and how she silently struggles to put her life and livelihood together, both materially and metaphorically. Through a focus on the subversive act of return, I critique the existing notion that red-light districts like Sonagachi lie at the end of the human wasteland, a place to escape from rather than return to. ${ }^{2}$ Nita-di, who was in fact trafficked and has built her home and livelihood in Sonagachi, and even returns to it, urges us to extend our thinking about the aftermath of the raid as it unfolds in the immediacy of the brothel.

\section{What is a Raid?}

Nita-di's ${ }^{3}$ story is not unique. Her experience overlaps with that of several sex workers I have come to know since 2011. Raids have emerged as an important subject of analysis since the surge in the global anti-trafficking narrative in the early 2000s. ${ }^{4}$ The connotation of the raid as an anti-trafficking instrument varies widely, depending on one's position on the question of sex work. Radical feminists consider 'prostitution' as the paradigmatic example of patriarchal violence ${ }^{5}$ and, with the rise of 'carceral feminism', ${ }^{6}$ the raid is seen

2 K Millar, 'The Precarious Present: Wageless labor and disrupted life in Rio de Janeiro, Brazil', Cultural Anthropology, vol. 29, no. 1, 2014, pp. 32-53, https:// doi.org/10.14506/ca29.1.04.

3 At DMSC, most of the women, including myself, refer to each other as Didi or an abbreviated -di after the name. Though Didi indicates older sister, at DMSC, this can be interpreted both as a mark of kinship and sisterhood, irrespective of age.

4 A T Gallagher, The International Law of Human Trafficking, Cambridge University Press, New York, 2012; J Chuang, 'Rescuing Trafficking from Ideological Capture: Prostitution reform and anti-trafficking law and policy', University of Pennsylvania Law Review, vol. 158, 2010, pp. 1656-1728; J Chuang, 'Exploitation Creep and Unmaking the Human Trafficking Law', The American Journal of International Law, vol. 108, no 4, 2014, pp. 609-649, https://doi.org/10.5305/ amerjintelaw.108.4.0609.

5 C MacKinnon, 'Feminism, Marxism, Method and the State: An agenda for theory', Signs, vol. 7, no. 3, 1982, pp. 515-544; C Pateman, 'Defending Prostitution: Charges against Ericsson', Ethics, vol. 93, no. 3, 1983, pp. 561-565; K Barry, The Prostitution of Sexuality: The global exploitation of women, New York University Press, New York, 1995; S Jeffreys, The Industrial Vagina: The political economy of the global sex trade, Routledge, New York, 2009; A Dworkin, 'Prostitution and Male Supremacy', Michigan Journal of Gender and Law, vol. 1, issue 1, 1993, pp. 112.

6 E Bernstein, "Carceral Politics as Gender Justice? The "traffic in women" and neoliberal circuits of crime, sex, and rights', Theory and Society, vol. 41, issue 3, 2012, pp. 233-259, https://doi.org/10.1007/s11186-012-9165-9. 
as a tool of the criminal justice system that advocates punitive measures for traffickers and the rescue and rehabilitation of 'victims'. Feminists who support sex workers' rights distinguish consent from coercion; ${ }^{7}$ hence, they see the raid as a punitive device that threatens the livelihood of sex workers. ${ }^{8}$ Selected public health literature conceives the raid as a form of human rights violation against sex workers that drives the commerce out of sight and severely threatens sex workers' access to health care, especially as it relates to HIV/AIDS prevention. In 2014, The Lancet published a series of articles, titled 'HIV and Sex Workers', which sought to '...investigate the complex issues faced by sex workers worldwide, and call[ed] for the decriminalisation of sex work, in the global effort to tackle the HIV/AIDS epidemic." In the realm of human rights, based upon evidence drawn from UN agencies, such as the World Health Organization, UNAIDS, and the UN Special Rapporteur on the Right to Health, Amnesty International also proposed the decriminalisation of sex work to ensure access to health care, human rights, and justice. ${ }^{10}$

The Indian legal system poses a particular conundrum: The Immoral Traffic (Prevention) Act does not declare prostitution as illegal or recognise sex work as a legitimate form of labour. On the ground, however, this ambiguity is insignificant; the state, especially the police, routinely label sex workers as a group as either 'criminals' or 'victims'. Thus, in an effort to establish sex work as a legitimate form of labour and delink it from trafficking, DMSC established the Self-Regulatory Board (SRB) in 1997 to closely monitor the recruitment of minors and/or unwilling women into sex work in Sonagachi. The SRB is also critical in establishing DMSC's commitment to anti-trafficking work.

7 K Kempadoo, 'Introduction: Globalizing Sex Workers' Rights' in K Kempadoo and J Doezema (eds.), Global Sex Workers: Rights, resistance and redefinition, Routledge, New York, 1998, pp. 1-27; J Doezema, Sex Slaves and Discourse Masters: The construction of trafficking, Zed Books, New York, 2010; T Zheng (ed.), Sex Trafficking, Human Rights and Social Justice (Routledge Research in Human Rights), Routledge, New York, 2010; S Dewey and P Kelly, Policing Pleasure: Sex work, policy and state in global perspective, NYU Press, New York, 2011.

8 M Ditmore and J Thukral, 'Accountability and the Use of Raids to Fight Trafficking', Anti-Trafficking Review, issue 1, 2012, pp. 134-148, https://doi.org/ 10.14197/atr.201218; A Hill, 'How to Stage a Raid: Police, media and the master narrative of trafficking', Anti-Trafficking Review, issue 7, 2016, pp. 3955, https://doi.org/10.14197/atr.20121773; V Magar, 'Rescue and Rehabilitation: A critical analysis of sex workers' anti-trafficking response in India', Signs, vol. 37, no. 3, 2012, pp. 621-23, https://doi.org/10.1086/662698.

9 'HIV and Sex Work', The Lancet, 23 July 2014, retrieved 3 July 2017, http:// www.thelancet.com/series/HIV-and-sex-workers.

10 Amnesty International, Decision on State Obligations to Respect, Protect and Fulfill the Human Rights of Sex Workers, 2016, retrieved 3 July 2018, https:// www.amnesty.org/en/policy-on-state-obligations-to-respect-protect-and-fulfilthe-human-rights-of-sex-workers. 
Critics of the raid-rescue-rehabilitation paradigm primarily examine the institutional aftermath, which includes the arbitrary construction of 'victims', the carceral conditions of shelters, rescue driven by market humanitarianism, etc. ${ }^{11}$ This article aligns with this body of work; however, I shift the focus to the material trace of the raid in the brothel to ask what this detritus means in terms of the everyday labour and livelihood of those who inhabit that space as ghar (home). Ethnographically, I interweave the trace in its instant material destruction, the lives of the sex workers conjured by the detritus the next day, and finally, the return of (some) sex workers who managed to escape. I particularly emphasise materiality, first to mark the violent pathways through which the state generates the detritus. Second, I argue that, for the sex workers, the detritus is not something they abandon but return to, as one would to ordinary everyday things, to reclaim and rebuild their lives and livelihood. Sex workers specifically used atyachar (oppression) to describe the violence of raids. As one of them once rhetorically posed, 'After all, what is a raid? It is only arek rokomer atyachar (another form of oppression)'. Another sex worker noted, 'It (raid) may happen today, tomorrow or the day after, who knows?' Others who were present nodded in agreement. Nita-di, too, had once observed rather ironically, 'If there is anything reliable in our lives, it is atyachar.' Raids as atyachar thus signify a specific manifestation of violence-unpredictable but inevitable. More importantly, the women experienced the raid not as a spectacle but as an ordinary practice of the state to violently reinforce their marginalisation.

What struck me when I started my fieldwork was that I did not observe any obvious trepidation about raids amongst the women. Instead, the dominant narrative was that of escape and return. Compared to the ordinariness of the raid, the return was especially seen as extraordinary. As a way to strategise, the women would regularly instruct one another that, 'All you have to do is to wait for things to quieten, for the police suspicion to abate, before you return.

11 E Shih, 'Freedom Markets: Consumption and commerce across human-trafficking rescue in Thailand', positions, vol. 25, no. 4, 2017, pp. 769-794, https://doi.org/ 10.1215/10679847-4188410; V Ramachandran 'Critical Reflections on Raid and Rescue Operations in New Delhi', Open Democracy, 25 November 2017, retrieved 2 November 2018, https://www.opendemocracy.net/beyondslavery/ vibhuti-ramachandran/critical-reflections-on-raid-and-rescue-operations-innew-delhi; M Ditmore, 'The Use of Raids to Fight Trafficking in Persons', Sex Workers Project, Urban Justice Center, New York, 2009; G Soderlund, 'Running from the Rescuers: New U.S. crusades against sex trafficking and the rhetoric of abolition', NWS A Journal, vol. 17, no. 3, 2005, pp. 64-87; M Seshu, A Pai, L Murthy and VAMP, Raided: How anti-trafficking strategies increase sex workers vulnerability to exploitative practices, SANGRAM, Sangli, 2018; K Walters, 'Violence of Rescue and (Mis)calculation of Rehabilitation', Economic and Political Weekly, vol. 51, issue 44-45, 2016, pp. 55-61. 
Make sure you have some condoms in your bag to work and eat when you are away.' Here, it is important to note two interrelated issues. First, like other work-home convergent spaces, the brothel as ghar challenges the separation between the private and the public, but the state uses tropes of immorality and criminality to justify the assault on brothels. Second, considering that DMSC's labour collectivisation is primarily brothel-based, the disruption of that space also signifies disruption of the labour movement. Therefore, while returning after a raid is not new in Sonagachi, since the foundation of DMSC, return is mobilised as a political act of reclaiming one's ghar and subverting the state. In weaving the ethnography with the postcolonial feminist framework, ${ }^{12}$ we may then ask, how does one come to inhabit a place that is continually violated but is also the space for labour collectivisation?

\section{The Human Trace}

In June 2014, the police arrived in the late evening to raid NandaRanir Bari, one of the prominent brothels in Sonagachi. Even if the police had a warrant, they did not produce it or feel the need to do so. The raid was troubling mainly in its familiarity — sudden and swift. As the day was winding down, I was sitting with members of the SRB in the DMSC office, discussing some of the complicated cases the members had to deliberate. A sudden commotion rolled down the street, and, as I looked out, police jeeps and vans moved in to block the entrance to the brothel. Customary refrains poured in from the DMSC

${ }^{12} \mathrm{~J}$ D'Cunha, 'Prostitution: The contemporary feminist discourse' in M Thappan (ed.), Embodiment: Essays on gender and identity, Oxford University Press, New Delhi, 1997, pp. 230-251; C T Mohanty, 'Under Western Eyes: Feminist scholarship and colonial discourses', Feminist Review, vol. 30, issue 1, 1988, pp. 65-88, https://doi.org/10.1057/fr.1989.1; R Sunder Rajan, The Scandal of the State: Women, law and citizenship in postcolonial India, Duke University Press, Durham, 2003; A Ahmed and M Seshu, 'We Have the Right Not to be "Rescued"...: When anti-trafficking programs undermine the health and well-being of sex workers', Anti-Trafficking Review, issue 1, 2012, pp. 149-164, https://doi.org/10.14197/ atr.201219; P Kotiswaran, Dangerous Sex and Invisible Labor: Sex work and law in India, Princeton University Press, Princeton, 2011; S P Shah, 'Sex Work in the Global Economy', New Labor Forum, vol. 12, issue 1, 2003, pp. 74-81, https:// doi.org/10.1080/714035885; P Govindan, 'Rethinking Emancipation: The rhetorics of slavery and politics of freedom in anti-trafficking work in India', Interventions: International journal of postcolonial studies, vol. 15, issue 4, 2013, pp. 511-29, https://doi.org/10.1080/1369801X.2013.849421; S P Shah, Street Corner Secrets: Sex, work and migration in the city of Mumbai, Duke University Press, Durham, NC, 2014; S Basu, The Trouble with Marriage: Feminists confront law and violence in India, University of California Press, Berkeley, 2015; S Ghosh, The Gendered Proletariat: Sex work, workers' movement, and agency, Oxford University Press, New Delhi, 2017. 
members as we rushed down the stairs to go to NandaRanir Bari: 'Minors? Or women who they (the police) think look like minors?'; 'Somebody tipped them (police) off'; 'Do they have the papers (warrant)?' Constables in khaki uniforms had cordoned off the house, warding off curious onlookers who had gathered around. Purnima-di, who was the director of the Board at that time, hollered at the crowd to give her way; she was trying to reach the police officer who was supervising the raid, someone she had interacted with previously in Lalbazaar, the police headquarters in Kolkata. The officer told Purnima-di that she had 'reliable' information that there are nabalikas (minors) in this brothel. In response, Purnima-di deferentially explained that she was familiar with all the women, and, to her knowledge, there were 'no girls below 18. They all have been presented at the SRB and have the DMSC card since they are all members.' In her habitual patronising tone, the police officer said, 'Come to Lalbazaar tomorrow; we'll see.' As the other DMSC members shouted in protest, 'Let us in; we know the women in there', the officer turned annoyed to Purnima-di: 'Control your women. We are trying to do something important here.' The raid continued while we stood helplessly as mere auditory witnesses to doors being broken, screams of help, and heavy boots on the stairs. Finally, a handful of women were dragged out and driven away in police vans.

The next morning, I accompanied Purnima-di to NandaRanir Bari. I had witnessed raids over the course of my fieldwork, but this was the first time I returned to the site the day after. The trace of violence was evident everywhere: broken locks, damaged furniture, clothes and belongings strewn on the floor, splattered food, and spilled drinks. As we continued, Purnima-di pointed to a specific bed in one of the rooms with the cracked box drawer underneath pulled out. She explained that during the raid, the police alleged that there was a minor hiding in the box drawer. Purnima-di knew the woman, Mina, well and had introduced me to her two summers ago. Unlike many other Acategory $^{13}$ sex workers, Mina was a member of DMSC. Though I never saw her attending meetings or participating in any public demonstrations, she took an active interest in the work of the organisation. I recalled that on previous visits, our customary first stop was Mina's room. However, that day, I heard Purnima-di wearily muttering to herself, 'She is not a minor by any chance. She is at least 25. I told Barababu (the local police chief) but he would not listen.'

13 Sex workers in Sonagachi informally rank themselves into A, B, and C categories based on their earning scale, A being the highest paid. 
The detritus summoned the lives of the disappeared women. I recalled some of my conversations with Mina in this very room; I was especially struck by her financial planning. When she learnt about my rather weak financial acumen, she was concerned about my future and offered me the details of her own diverse investment portfolio in land, real estate, and export fisheries. Mina's earnings, per customer, ranged between INR 3,500 and 5,000 (approximately, USD 55-77), 'depending on the service I provide. They are all tailored to customer needs, so my earning varies.' Mina is acutely aware that the window she has during which to earn a higher wage is short, that is, between ages 1830 , '... so I want to make the best of it. I have carefully organised my life since I came to Sonagachi. I have built a house outside my village where I will live upstairs once I leave this work. My fisheries business is going well. And Didi, did you know that the prawn that you eat in the US may be from my fishery?' As I was reflecting on our plausibly interconnected worlds of fish, labour, and research, Mina's possessions lay abandoned on the floor in utter neglect. Like her finances, she always kept her room meticulously organised, so the sight of disorder signalled, perhaps, an irreversible change in Mina's life. Will Mina return? I posed the question to Purnima-di, to which she poignantly responded, 'We will go the CWC (Child Welfare Committee) after this and see what we can do to release her. They should not have taken her at all; she is not a minor.' As we stepped out into the veranda to go visit the other rooms, Purnima-di rhetorically observed, 'Who knows if this polisi atyachar (police oppression) will ever end?' Atyachar, as I noted earlier, appears in routine conversations in Sonagachi, and is not necessarily limited to describe the experience of raids but the ordinary struggles to earn a livelihood especially in relation to state violence.

On any other day, as a shared space, the veranda would be difficult to navigate, with the sex workers walking up and down, tending to their everyday chores, chatting, laughing, and hollering. That day, it was uncannily silent. We arrived at Nita-di's room. Nita-di had lived in this brothel for almost two decades and had managed to purchase her room along with another one, which she ran as a malkin (brothel-owner) on an adbiya ${ }^{14}$ basis. Like Mina's, her room was in complete chaos. I tried to imagine Nita-di fleeing: the door of the wooden almirah was still open; perhaps in the rush to take her granddaughter's gift with her, she forgot to close it. Or the police may have left it that way the night before. The vegetables from the cooking area had rolled all over the room, and the green chilies, mashed by heavy boots, had filled the room with a caustic drift. The emptiness spoke piercingly about the lives of the women who occupied these spaces, and the human trace was unmistakable in what was left behind by the violence. We saw Sunil, the cook for NandaRanir Bari, at the

14 An arrangement where the income is equally split between the sex worker and the malkin. 
doorway as we were leaving. He asked me to come back: 'When the Didis return, I will cook a good meal for all of us.' Purnima-di replied, 'Let me know once they are back', with a mirthless smile, indicating her acute awareness of both the difficulty and the necessity of the return. Sunil nodded in agreement, and we crossed the street to get some lunch at the local eatery. Sunil's plan for a future communal meal, and Purnima-di's request to update her, indicated that both of them were rather accustomed to this kind of displacement and expected normalcy to return as soon as the Didis did.

We spent the afternoon at a meeting with the CWC officers, inquiring about the women who were picked up by the police the previous night. Purnima-di specifically wanted to know how many held in custody were being considered 'minors'. 'Mina is certainly not a minor', Purnima-di insisted. 'Sir, the SRB has documents to prove that NandaRanir Bari did not have minors. We have their bone scan results; they are above 18.' Hearing Purnima-di mention NandaRanir Bari seemed to irritate one of the officers. He quickly retorted by saying, 'This specific brothel, this NandaRanir Bari, is a notorious place! They say that they have A-category women, but they are in fact all minors who have been trafficked. We have to rescue children from this terrible situation. It is our job.' Such deflections that emphasise the immorality of the brothel over the grassroots labour movement, and ignore DMSC's anti-trafficking work, were rather common across state actors. Especially, the male state officials took pride in never having visited Sonagachi as a way to assert their moral rectitude and the larger politics of respectability. Therefore, the obliterability of the brothel needs to be located within the dominant narrative of not just criminality but immorality as well.

We did not make much progress that day in terms of determining where the women were being held and on what charges. This visit to the CWC was not an exception. Typically, Purnima-di and other sex workers refrained from making further demands on the CWC, as they seldom were able to procure information related to the 'minors'. As one sex worker put it, 'We cannot tell the police or the CWC people how terrible they make us feel as chbotolok (of lower socioeconomic strata); they will oppress us even more. If we knew this was the first time and the last time, maybe we would have. But we know this is forever.' The sex workers often challenged the state-construction of the brothel as a purely public space inhabited by 'fallen' women who reject monogamy. Though their voices were mostly inaudible to the state, nonetheless, it is through collectivisations like Durbar, for the first time in India, that we hear the voices of the sex workers themselves claiming rights. ${ }^{15}$

${ }^{15}$ S Ghosh, 2017. 
Purnima-di looked dejected, as she had been diligently directing the SRB's work to prevent trafficking in Sonagachi. I asked her if she expected some of the women to return. Her response was slow and thoughtful: 'All these women, who are not minors, who have not been trafficked, are taken away constantly. This is our home; this is not just a brothel as that man at the CWC said. So much is at stake, their things, their livelihood, DMSC, everything is here; they have to return.' Unlike some of the literature on raids that emphasises the loss of access to health programmes, these two days offered me little evidence that this would be a primary concern for those who escaped. I still asked Purnima-di, 'What will happen to their ICTC?'16 The question seemed rather misplaced to her, but she patiently responded, 'Well, I am sure those who escaped took condoms with them; they usually have them in their handbags. That's all they need for now to do some work, fill their stomachs, till they can return.' Purnima-di was primarily concerned about Mina and others who were being held by the state, most likely at homes (shelters), and understandably so. The carceral nature of the homes was palpable on my visits to some of them with Purnima-di in the past, and the existing literature offers extensive evidence of rights violation of the detained women. ${ }^{17}$

\section{The Broken Pieces}

Nita-di returned to NandaRanir Bari as quietly as she had left. I happened to run into her a month after the raid at the local sweetmeat shop where she had come to buy some as an offering for her daily household puja (worship). She asked me how I was doing. After we exchanged pleasantries, she invited me to lunch the next day. I arrived around $2 \mathrm{pm}$ at NandaRanir Bari and on the way to Nita-di's room, I passed Mina's room. The door was locked with a large padlock hanging on the latch; most likely, a new sex worker was now renting that room. I knocked on Nita-di's door. She answered with her characteristic warmth and asked me to take a seat, as she 'had to add the phoron (spice) to the daal, (lentils).' I settled on the mat on the floor and noticed that the room looked emptier but more orderly than what I had seen the last time. Nita-di had to discard the 'broken pieces to be able to go on.' The bed was ripped at the headboard, the almirah had drawers sticking out on broken grooves, and the kitchen area had fewer utensils than before. This was the second time she had successfully returned. 'I am fortunate', she observed. 'My room is still here, though everything else is gone.'

${ }^{16}$ Integrated Counselling and Testing Centres offer the routine HIV/AIDS testing in Songachi.

17 A T Gallagher and E Pearson, 'The High Cost of Freedom: A legal and policy analysis of shelter detention for victims of trafficking', Human Rights Quarterly, vol. 32, 2010, pp. 73-114. 
Despite the disquieting arc of violence, Nita-di's space had somewhat returned to the comfort that was familiar to me. I perceived this in Nita-di as well, as she settled near the kerosene stove to complete her cooking. 'I want you to know that I came to your room the day after the raid', I said in the spirit of disclosure and as a way to commence from where we left off. 'It made me very sad to see your things scattered on the floor. I recognised most of them, but, even if I wanted to, I could not put them back because of police orders.' 'I know. Sunil told me', she said in a neutral tone. Then, after a brief pause, Nita-di resumed,

'It must have affected you because things like this do not happen outside Sonagachi. But this is what we are used to. Police oppression will not go away, so we will have to find ways to escape but then also find ways to return. This is my home and this is the only place I could ever call home. It is only here I have some way to earn money to survive. I am not educated like you, so all I have is my gatar (body) to sell. But do I like it? Did I even want to get into line-er kaaj (sex work)? But here, at least I have been able to feed myself and take care of my daughter. So, this is all I know, like, you know, your home? And why don't the police just let us be in our homes? Who asked them to rescue us?'

Nita-di raised an important question about the validity of raid-as-rescue, as a larger humanitarian effort to 'save' women. Scholars have long critiqued this teleological narrative, which has led sex workers to defy their saviours and reject homes/shelters either by trying to escape or rebel. ${ }^{18}$ However, Nita-di's return and her reclamation of the brothel as home, and the right to inhabit it, shed light on the implications of the raid. The forced displacement endured by Nita-di and others like her signals a well-established narrative that the raid is both a juridical and a moral tool for controlling female transactional sexuality.

Nita-di's biography elucidates her travails further. She was married at seventeen. Her family was struggling to feed all the eight children, and, when a marriage proposal appeared, surprisingly without a demand for dowry, she was married off to a man who was in his 40s and 'suspected of some kind of mental illness.' The marriage had been difficult from the beginning since her husband, too, had very little means of income as a daily farm labourer. She, having worked on the farm before, joined her husband to boost the family income, but still they struggled to keep afloat. 'One day my husband said that we should go to Kolkata', Nita-di had once recounted to me.

18 Walters, 2016. 
'There are more jobs there since they are building a lot of houses in the city. So I thought he must know better, and we came to Kolkata. We came to Sealdah (one of the major railway stations in the city), and, then, after getting off a bus, I found myself here. I had heard of Sonagachi but did not know that this is where it was, but something did not seem right. The women were all standing outside wearing a lot of makeup. But I slowly understood that my husband had already talked to a man whom we met at the tea stall and had arranged for me to be here in NandaRanir Bari. "You will make a very fine catch and we will never have to worry about money again", he had told me.'

Nita-di's voice had deepened as she struggled to manage that fine line between betrayal and survival. 'I agreed to sell my body', she told me in the end. Nitadi was long estranged from her husband. However, she adhered to the Hindu signs of marriage. Every day, she religiously applied sindur (vermillion) in the parting of her hair after taking a shower alongside the red tip, round mark on the forehead, and also wore the $s(n) a k h a$ (shell bangles) and the pala (ideally, a pair of coral bangles but which are mostly made of lac).

Her account deeply resonated with several other women who arrived in Sonagachi through a similar path, and their experiences of escape and return. As Nita-di's story of return unfolded rather quietly, a modicum of agency was palpable in her as well as in the others who returned. While we were finishing our lunch, Kamala-di, another sex worker who had escaped and managed to return, came to the door. 'Didi', she said to me, 'We don't want to leave; who wants to leave their home? And when they rescue us, they send us to these awful homes, teach us how to use sewing machines. Now, how much money can I earn by sewing clothes, when I can earn way more here in one sitting? But at the end, we will try to return because we have to fight for rights.' Yet, as the women worked to collect their lives and put the broken pieces together, they seldom discussed the raid and the disruptions it caused. They only mentioned it sporadically and somewhat indifferently, as though raids were ordinary occurrences.

Despite the state's claim to induct rescued women into vocational training in order for them to leave sex work, and the red-light district for that matter, most sex workers perceived this apparent benevolence as an incursion on their already well-established livelihood. Likewise, though the sex market in Sonagachi is informally organised, nonetheless, over time, the women develop a keen understanding of its underlying principles to maximise their incomes. One such aspect is the 'repeat' customer. Sex workers have shared with me details about how they invest — mainly affectively — in a few select customers for a reliable income. Sometimes, the 'repeat' customer becomes a lover, offering the women the much-desired need for emotional security, and even simulated 
domesticity. The other aspect that becomes apparent in the conversation between Nita-di and Kamala-di above is the collective experience of displacement and return, a duality that is rooted in a bond of kinship and labour collectivisation facilitated by the brothel as their shared home.

\section{Conclusion}

The arc of the raid I present here is based on the experiences of the sex workers. These experiences are certainly different, as is the outcome; that is, while one woman surreptitiously returns and the other one is forcibly displaced by the state, together, they nonetheless deepen our understanding of the aftermath of the raid beyond its institutional ramifications. The material trace of the violence, as I emphasised through the detritus, offers another way to think about lives that are upended. At the same time, the detritus reminds us of those lives displaced and how that detritus itself becomes the anchor when sex workers like Nita-di return as an act of defying the state. Beyond the raidrescue-rehabilitation paradigm, a focus on the brothel as a space of violence and of return signals a disconnect between the sex worker rights movement and state initiatives to curb trafficking. This disconnect is explored globally in the many studies produced by sex workers and sex worker organisations, the 2017 Amnesty International policy ${ }^{19}$ and the 2018 report by the Global Alliance Against Traffic in Women ${ }^{20}$ and has resulted in calls to decriminalise sex work. Through the use of ethnographic material, this article shows how this disconnect works on the ground and the repercussions it has for the lives and livelihoods of sex workers.

Simanti Dasgupta is an Associate Professor of Anthropology and a Human Rights Centre Fellow at the University of Dayton. Her overarching interest in the politics of citizenship in postcolonial and neoliberal nation-states links her works. She is currently preparing her book manuscript, tentatively titled Prophylactic Rights: Sex Work Movement, HIV/AIDS and Anti-Trafficking in Neoliberal India, based on her long-term ethnographic research with DMSC. She has published in the Journal of South Asian Studies, PoLAR: Political and Legal Anthropology Review, Open Democracy and is the author of BITS of Belonging: Information Technology, Water and Neoliberal Governance in India (Temple, 2015). Email: sdasgupta1@udayton.edu

19 Amnesty International, 2016.

${ }^{20}$ Global Alliance Against Traffic in Women, Sex Workers Organising for Change: Selfrepresentation, community mobilization and working conditions, GAATW, Bangkok, 2018. 